\title{
FAKTOR-FAKTOR YANG BERHUBUNGAN DENGAN KEJADIAN KURANG ENERGI KRONIS (KEK) PADA IBU HAMIL DI PUSKESMAS WARUNG JAMBU KOTA BOGOR
}

\author{
Indriati Fitrianingtyas ${ }^{1}$, Fenti Dewi Pertiwi ${ }^{2}$,Wina Rachmania ${ }^{3}$
}

\begin{abstract}
${ }^{1}$ Konsentrasi Kesehatan Reproduksi dan Kesehatan Ibu Anak (KIA), Program Studi Kesehatan Masyarakat Fakultas Ilmu Kesehatan, Universitas Ibn Khaldun Bogor. Email : fitrianingtyas04@gmail.com,

${ }^{2}$ Konsentrasi Kesehatan Reproduksi dan Kesehatan Ibu Anak (KIA),Program Studi Kesehatan Masyarakat Fakultas Ilmu Kesehatan, Universitas Ibn Khaldun Bogor, Email: fenti.dewi.pertiwi@gmail.com

${ }^{3}$ Konsentrasi Kesehatan Reproduksi dan Kesehatan Ibu Anak (KIA),Program Studi Kesehatan Masyarakat Fakultas Ilmu Kesehatan, Universitas Ibn Khaldun Bogor
\end{abstract}

\begin{abstract}
Abstrak
Kurang Energi Kronis (KEK) pada wanita hamil adalah status gizi kurang seseorang karena ketidakseimbangan antara asupan pemenuhan kebutuhan dan pengeluaran energi. World Health Organization (WHO) melaporkan bahwa prevalensi anemia pada kehamilan dan KEK secara global 35-75\% secara signifikan meningkat pada trisemester ketiga dibandingkan trimester pertama dan kedua kehamilan. Tujuan penelitian ini adalah mengetahui faktor-faktor yang berhubungan dengan Kejadian KEK pada ibu hamil di Puskesmas Warung Jambu Kota Bogor tahun 2017. Penelitian ini menggunakan desain cross Sectional. Sampel dalam penelitian ini 43 responden dengan teknik sampel random sampling. Alat yang digunakan dalam penelitian ini adalah kuesioner dan pita LiLA (lingkar lengan atas). Hasil penelitian menunjukkan bahwa ada hubungan antara pengetahuan tentang gizi ( $\mathrm{p}$ value $=0,004) \mathrm{RR}=2,222$, penyakit infeksi ( $\mathrm{p}$ value $=0,000) \mathrm{RR}=0,227$ pemeriksaan kehamilan dan ANC ( $\mathrm{p}$ value $=0,000) \mathrm{RR}=2,700$ dengan kejadian KEK pada ibu hamil. Kesimpulan penelitian ini menunjukkan adanya hubungan antara pengetahuan, penyakit infeksi dan ANC (Antenatal Care) dengan kejadian KEK pada ibu hamil. Saran yang dapat diberikan adalah memberikan penyuluhan mengenai bahaya KEK pada ibu hamil serta pengetahuan pentingnya gizi, dan pemeriksaan kehamilan oleh petugas kesehatan
\end{abstract}

Kata kunci: Kronis Kurang Energi, pengetahuan, ibu hamil

\section{Latar Belakang}

Pembangunan kesehatan pada periode 2015-2019 adalah program indonesia sehat dengan sasaran meningkatkan derajat kesehatan dan status gizi masyarkat melalui upaya kesehatan dan pemberdayaan masyarakat yang didukung dengan perlindungan finansial dan pemerataan pelayanan kesehatan. Sasaran pokok RPJMN 2015-2019 adalah : (1) meningkatnya status kesehatan dan gizi ibu dan anak; (2) meningkatnya pengendalian penyakit; meningkatnya akses dan mutu pelayanan kesehatan dasar dan rujukan terutama di daerah terpencil, tertinggal dan perbatasan; (4) meningkatnya cakupan pelayanan kesehatan universal melalui Kartu Indonesia Sehat dan kualitas pengelolaan SJSN kesehatan; (5) terpenuhinya kebutuhan tenaga kesehatan, obat dan vaksin ; serta (6) meningkatkan responsivitas sistem kesehatan. (Renstra Kemenkes RI, 2015). Tujuan pembangunan tertuang dalam Sustainable Development Goals (SDGs), terdapat 17 tujuan pembangunan berkelanjutan 2030 yang ditargetkan. Salah satu dari tujuan SDGs 
adalah non kelaparan yaitu mengakhiri segala bentuk malnutrisi, termasuk mencapai target internasional 2025 untuk penurunan stunting dan wasting pada balita serta mengatasi kebutuhan gizi remaja perempuan, wanita hamil dan menyusui serta lansia. (Kemenkes RI, 2015).Status gizi yang baik merupakan salah satu keberhasilan pembanguan kesehatan yang pada dasarnya adalah bagian yang tak terpisahkan dari pembangunan nasional secara keseluruhan. Balita, anak usia sekolah dasar, dan ibu hamil yang merupakan kelompok sasaran yang sangat perlu mendapat perhatian khusus karena dampak negatif yang ditimbulkan apabila menderita kekurangan gizi. (Permenkes RI No 51 tahun 2016).Menurut Sedioetama (2010) dalam Yuliastuti (2014), empat masalah gizi utama di Indonesia yaitu Kekurangan Energi Kronik (KEK), Gangguan Akibat Kekurangan Yodium (GAKY), Kekurangan Vitamin A (KVA), dan Anemia Gizi Besi (AGB). KEK adalah penyebab dari ketidak seimbangan antara asupan untuk pemenuhan kebutuhan dan pengeluaran energi. Menurut Rukiah (2010) dalam Ardani (2015), organisasi kesehatan dunia (WHO) melaporkan bahwa prevalensi anemia dan KEK pada kehamilan secara global $35-75 \%$ dimana secara bermakna tinggi pada trimester ketiga dibandingkan dengan trimester pertama dan kedua kehamilan. WHO juga mencatat $40 \%$ kematian ibu di negara berkembang berkaitan dengan anemia dan KEK dengan prevalensi terbanyak dari kasus tersebut karena ibu Kurang Energi Kronis (KEK) yang dapat menyebabkan status gizinya berkurang.
Pada tujuan SDGs 2015-2030 target nasional ibu hamil KEK adalah 5\% sehingga target ibu hamil non KEK adalah 95\% (Kemenkes RI, 2015). Sedangkan hasil Riset Kesehatan Dasar tahun 2013 prevalensi KEK wanita hamil umur 15-49 tahun adalah 24,2\% Hasil tersebut menunjukan bahwa prevalensi risiko KEK pada ibu hamil masih tinggi.Sebanyak 13 propinsi dengan prevalensi risiko KEK nasional salah satunya adalah Jawa Barat dimana data menunjukan peringkat ke-12 dari 33 provinsi ibu hamil KEK. Prevalensi wanita usia subur risiko kurang energi kronis (KEK) menurut umur tahun 2007 dan 2013. Secara keseluruhan, prevalensi risiko kurang energi kronis naik pada semua kelompok umur dan kondisi wanita (hamil dan tidak hamil). Pada wanita tidak hamil kelompok umur 15-19 tahun prevalensinya naik 15,7 persen. Demikian juga pada wanita hamil kelompok umur 45-49 tahun naik 15,1 persen. (Riskesdas, 2013). Data Dinas Kesehatan Kota Bogor tahun 2016 menunjukan bahwa jumlah keseluruhan ibu hamil yang mengalami Kurang Energi Kronis (KEK) dari 24 puskesmas di kota Bogor sebanyak 1.141 ibu hamil. Data menunjukan masih tingginya jumlah ibu hamil yang megalami Kurang Energi Kronis di Kota Bogor.

Puskesmas Warung Jambu merupakan salah satu Puskesmas di wilayah Kota Bogor yang terletak di Kelurahan Bantar Jati Kecamatan Bogor Utara. Wilayah kerja Puskesmas Warung Jambu terdiri dari tiga kelurahan yaitu kelurahan Kedung Halang, kelurahan Ciparigi dan kelurahan Ciluar, data penelitian puskesmas pada tahun 2015 terdapat ibu hamil Kekurangan Energi Kronik 
sebanyak 2,9\% dari jumlah sasaran ibu hamil 1362 dan pada tahun 2016 terdapat sekitar 4,4\% dengan KEK dari jumlah sasaran ibu hamil $1370 \mathrm{ibu}$ hamil, bahwa ada peningkatan sekitar 1,5\% dari tahun 2015 s/d 2016 ibu hamil yang mengalami Kekurangan Energi Kronis, dimana target Puskesmas Warung Jambu tahun 2016 ibu hamil KEK adalah 0\% (LB3 KIA dan Laporan Tahunan Gizi Puskesmas Warung Jambu, 2016).

Menurut Arisman (2007), terdapat beberapa penyebab yang mempengaruhi kebutuhan ibu akan zat gizi tidak terpenuhi yaitu disebabkan karena asupan makanan yang kurang dan penyakit infeksi, ibu hamil yang asupan makanannya cukup tetapi menderita sakit maka akan mengalami gizi kurang dan ibu hamil yang asupan makanannya kurang maka daya tahan tubuh akan melemah dan akan mudah terserang penyakit, tingkat pendidikan yang rendah, pengetahuan ibu tentang gizi kurang, pendapatan keluarga yang tidak memadai, usia ibu yang kurang dari 20 tahun atau lebih dari 35 tahun sehingga berpengaruh pada kebutuhan gizinya, paritas ibu yang tinggi atau terlalu sering hamil dapat menguras cadangan zat gizi tubuh, jarak kelahiran yang terlalu dekat menyebabkan ibu tidak memperoleh kesempatan untuk memperbaiki tubuh setelah melahirkan, ibu hamil yang bekerja membutuhkan lebih banyak energi karena cadangan energinya dibagi untuk dirinya sendiri dan janin. Sedangkan menurut Persatuan Ahli Gizi Indonesia (1999) dalam Supariasa (2002), menyebutkan bahwa faktor penyebab gizi kurang di pengaruhi oleh faktor penyebab langsung seperti asupan makanan dan penyakit infeksi, faktor penyebab tidak langsung yaitu persediaan makanan dirumah, perawatan anak dan ibu hamil, dan pelayanan kesehatan, pokok masalah terdiri dari keiskinan, kurang pendidikan, dan kurang keterampilan serta akar masalah meliputi krisis ekonomi.

Meningkatnya ibu hamil yang mengalami Kurang Energi Kronis (KEK) di Puskesmas Warung Jambu, sehingga peneliti tertarik untuk melakukan penellitian tentang "Faktor Faktor yang Berhubungan dengan Kejadian Kurang Energi Kronis (KEK) pada Ibu Hamil di Wilayah Kerja Puskesmas Warung Jambu Kota Bogor Tahun 2017".

Adapun tujuan penelitian ini adalah mengetahui hubungan pengetahuan ibu hamil tentang gizi dengan kejadian Kurang Energi Kronis (KEK), hubungan penyakit infeksi ibu hamil dengan kejadian Kurang Energi Kronis (KEK), hubungan pemeriksaan kehamilan ANC (Antenatal Care) dengan kejadian Kurang Energi Kronis (KEK) pada ibu hamil di Puskesmas Warung Jambu Kota Bogor tahun 2017.

Ruang Lingkup Penelitian ini untuk mengetahui Faktor - Faktor yang Berhubungan dengan Kejadian Kurang Energi Kronis pada Ibu Hamil di Puskesmas Warung Jambu Kota Bogor Tahun 2017. Penelitian ini dilaksanakan dari bulan April sampai Juli 2017. Populasi penelitian adalah seluruh ibu hamil di Puskesmas Warung Jambu Kota Bogor. Penelitian dilakukan kepada 43 responden ibu hamil. Penelitian ini perlu dilakukan karena masalah ibu hamil yang mengalami Kurang Energi Kronis meningkat di Puskesmas Warung Jambu Kota Bogor Tahun 2017. 


\section{Metode}

Desain penelitian ini menggunakan desain penelitian Cross Sectional dengan menggunakan pendekatan kuantitatif, penelitian crosssectional merupakan suatu penelitian untuk mempelajari dinamika kolerasi antara faktor-faktor risiko dengan efek, dengan pendekatan observasi, atau pengumpulan data sekaligus pada suatu saat (Notoatmodjo, 2010). Penelitian ini untuk melihat faktor-faktor yang berhubungan dengan kejadian Kurang Energi Kronis (KEK) pada ibu hamil di Puskesmas Warung Jambu Kota Bogor, Jawa Barat tahun 2017 dengan pengumpulan data yang dilakukan dalam waktu yang bersamaan antara variabel dependen dan variabel independen.

Populasi dalam penelitian ini yaitu seluruh ibu hamil yang berada di wilayah kerja Puskesmas Warung Jambu Kota Bogor, Jawa Barat dengan jumlah populasi sebanyak 1370 ibu hamil.Adapun sampel yang diambil adalah didasarkan pada 2 (dua) kriteria yaitu:

a. Kriterian inklusi sebagai berikut ; Ibu hamil yang dalam periode trisemester III yang dimana kebutuhan ibu hamil meningkat sampai akhir kehamilan, berada di wilayah kerja Puskesmas Warung Jambu Kota Bogor dan memiliki buku KIA atau tercatat di buku kohort petugas kesehatan. Bersedia diikutsertakan dalam penelitian dan pengisian kuesioner serta pengukuran LiLA (Lingkar Lengan Atas)

b. Kriteria eksklusi sebagai berikut ; Ibu hamil yang menolak diteliti, usia kehamilannya masuk dalam trisemester 1 dan 2, serta Ibu hamil yang sudah melahirkan pada saat penelitian.

Sampel yang telah digunakan, berjumlah 43 orang responden Penelitian ini terdapat empat variabel yaitu variabel independen mencakup faktor perilaku (pengetahuan dan pemeriksaan kehamilan ANC), dan faktor lingkungan (penyakit infeksi) sedangkan variabel dependen berupa kejadian Kurang Energi Kronis (KEK) pada ibu hamil.

Instrumen penelitian yang digunakan merupakan instrumen lama dari penelitian Mulyaningrum (2009) yang berjudul "Faktor- faktor yang Berhubungan dengan Risiko Kejadian Kurang Energi Kronis pada Ibu Hamil di Provinsi DKI Jakarta Tahun 2009". Dan penelitian Ningrum (2010) yang berjudul "Faktor- faktor yang Berhubungan dengan Risiko Kejadian Kurang Energi Kronis pada Ibu Hamil di Kelurahan Mampang, Pancoranmas, Depok Tahun 2010".

\section{Hasil}

1) Hubungan antara Pengetahuan tentang Gizi dengan Kejadian Kurang Energi Kronis (KEK)

Hasil penelitian, sebanyak 25 responden memliki pengetahuan kurang tentang gizi, dimana 10 responden $(40,0 \%)$ tidak mengalami KEK dengan ukuran LiLA $>=23,5 \mathrm{~cm}$ dan 15 responden $(60,0 \%)$ mengalami KEK dengan ukuran LiLA $<25,5 \mathrm{~cm}$. dan terdapat 18 responden memiliki pengetahuan baik tentang gizi. Dimana 16 responden $(88,9 \%)$ tidak mengalami KEK dengan ukuran LiLA $>=23,5 \mathrm{~cm}$ dan 2 responden $(11,1)$ mengalami KEK dengan ukuran LiLA $<25,5 \mathrm{~cm}$. 
Tabel 3.1 Hubungan Pengetahuan tentang Gizi dengan Kejadian Kurang Energi Kronis (KEK) di Puskemas Warung Jambu Tahun 2017

\begin{tabular}{|c|c|c|c|c|c|c|c|c|}
\hline \multirow{3}{*}{$\begin{array}{l}\text { Pengetahuan } \\
\text { Tentang Gizi }\end{array}$} & \multicolumn{4}{|c|}{ Kejadian KEK Berdasarkan LiLA } & & & \multirow{3}{*}{ P Value } & \multirow{3}{*}{$\begin{array}{c}\mathrm{RR} \\
(95 \% \mathrm{CI})\end{array}$} \\
\hline & \multicolumn{2}{|c|}{$\begin{array}{c}\text { Tidak KEK LiLA } \\
>=23,5 \mathrm{~cm}\end{array}$} & \multicolumn{2}{|c|}{$\begin{array}{l}\text { KEK LiLA } \\
<23,5 \mathrm{~cm}\end{array}$} & \multicolumn{2}{|c|}{ Total } & & \\
\hline & $\mathrm{N}$ & $\%$ & $\mathrm{~N}$ & $\%$ & $\mathrm{~N}$ & $\%$ & & \\
\hline Baik & 16 & 88,9 & 2 & 11,1 & 18 & 100 & 0,004 & $\begin{array}{c}2,222(1,338- \\
3,690)\end{array}$ \\
\hline
\end{tabular}

\begin{tabular}{rrrrrrr} 
Kurang & 10 & 40,0 & 15 & 60,0 & 25 & 100 \\
\hline Jumlah & 26 & 60,5 & 17 & 39,5 & 43 & 100 \\
\cline { 3 - 5 } & Dari & hasil & uji & statistik & & \multicolumn{3}{c}{ antara pengetahuan dengan Kejadian }
\end{tabular}
diperoleh nilai $p$-value $=0,004$. Oleh karena nilai $p<\alpha(0,05)$, maka dapat disimpulkan bahwa ada perbedaan proporsi kejadian Kurang Energi Kronis (KEK) responden yang memiliki pengetahuan tidak baik dan responden yang memiliki pengetahuan baik (ada hubungan Kurang Energi Kronis).Serta dari uji statistik juga di dapat nilai OR sebesar 12,0. Responden yang berpengetahuan kurang 12 kali lebih beresiko menderita Kurang Energi Kronis (KEK) dibandingkan dengan responden yang berpengetahuan baik.

\section{2)Hubungan antara Penyakit Infeksi dengan Kejadian Kurang Energi Kronis} (KEK)

Hasil penelitian menunjukan, terdapat 22 responden tidak ada penyakit infeksi yang diderita. Dimana 5 responden $(22,7 \%)$ tidak mengalami penyakit KEK, berbeda dengan ibu yang memiliki penyakit infeksi seluruh ibu tidak mengalami penyakit KEK seperti pada tabel 3.2 berikut ini

Tabel 3.2 Hubungan Penyakit Infeksi dengan Kejadian Kurang Energi Kronis (KEK) di Puskemas Warung Jambu Tahun 2017

\begin{tabular}{|c|c|c|c|c|c|c|c|c|}
\hline \multirow{3}{*}{$\begin{array}{l}\text { Penyakit } \\
\text { Infeksi }\end{array}$} & \multicolumn{4}{|c|}{ Kejadian KEK Berdasarkan LiLA } & & & \multirow{3}{*}{ P Value } & \multirow{3}{*}{$\begin{array}{c}\mathrm{RR} \\
(95 \% \mathrm{CI})\end{array}$} \\
\hline & \multicolumn{2}{|c|}{$\begin{array}{l}\text { Tidak KEK LiLA } \\
>=23,5 \mathrm{~cm}\end{array}$} & \multicolumn{2}{|c|}{$\begin{array}{l}\text { KEK LiLA } \\
<23,5 \mathrm{~cm}\end{array}$} & \multicolumn{2}{|c|}{ Total } & & \\
\hline & $\mathrm{N}$ & $\%$ & $\mathrm{~N}$ & $\%$ & $\mathrm{~N}$ & $\%$ & & \\
\hline Tidak Ada & 5 & 22,7 & 17 & 77,3 & 22 & 100 & 0,000 & $\begin{array}{c}0,227 \\
(0,105-0,491)\end{array}$ \\
\hline Ada & 21 & 100 & 0 & 0,0 & 21 & 100 & & \\
\hline Jumlah & 26 & 60,5 & 17 & 39,5 & 43 & 100 & & \\
\hline
\end{tabular}

Dari hasil uji statistik diperoleh nilaip-value $=0,000$. Oleh karena nilai $p<\alpha(0,05)$, maka dapat disimpulkan bahwa ada perbedaan proporsi kejadian Kurang Energi Kronis (KEK) responden tidak ada penyakit infeksi yang diderita dan responden ada penyakit infeksi yang diderita (ada hubungan antara peyakit infeksi dengan Kejadian Kurang Energi Kronis). Serta dari uji statistik juga di dapat nilai OR sebesar 0,227. Responden yang ada penyakit infeksi 0,227 kali lebih beresiko menderita Kurang Energi Kronis (KEK) dibandingkan dengan responden yang tidak ada penyakit infeksi. 
3)Hubungan antara Pemeriksaan

Kehamilan ANC (Antenatal Care) dengan Kejadian Kurang Energi

Kronis (KEK)

Hasil penelitian dari 43 responden terdapat 27 responden yang Pemeriksaan Kehamilan ANC dalam kategori kurang. Dimana 10 responden $(37,0 \%)$ tidak mengalami KEK dengan ukuran
LiLA $>=23,5 \mathrm{~cm}$ dan 17 responden $(63,0 \%)$ mengalami KEK dengan ukuran LiLA $<25,5 \mathrm{~cm}$. Selain itu, terdapat 16 responden yang pemeriksaan kehamilan dalam kategori baik, dimana 16 responden (100\%) tidak mengalami KEK dengan ukuran LiLA $>=23,5 \mathrm{~cm}$. seperti tergambar dalam tabel. 3.3 berikut ini:

Tabel 3.3 Hubungan Pemeriksaan Kehamilan ANC (Antenatal Care) dengan Kejadian Kurang Energi Kronis (KEK) di Puskemas Warung Jambu Tahun 2017

\begin{tabular}{|c|c|c|c|c|c|c|c|c|}
\hline \multirow{3}{*}{$\begin{array}{c}\text { Pemeriksaan } \\
\text { Kehamilan ANC }\end{array}$} & \multicolumn{4}{|c|}{ Kejadian KEK Berdasarkan LiLA } & & & \multirow{3}{*}{ P Value } & \multirow{3}{*}{$\begin{array}{c}\text { OR } \\
(95 \% \mathrm{CI})\end{array}$} \\
\hline & $\begin{array}{l}\text { Tidak } \\
>=\end{array}$ & $\begin{array}{l}\text { LiLA } \\
\mathrm{m}\end{array}$ & & & \multicolumn{2}{|c|}{ Total } & & \\
\hline & $\mathrm{N}$ & $\%$ & $\mathrm{~N}$ & $\%$ & $\mathrm{~N}$ & $\%$ & & \\
\hline Baik & 16 & 100 & 0 & 0,0 & 16 & 100 & 000 & $\begin{array}{c}2,700 \\
(1,651-4,415)\end{array}$ \\
\hline
\end{tabular}

\begin{tabular}{lcccccc} 
Kurang & 10 & 37,0 & 17 & 63,0 & 27 & 100 \\
\hline Jumlah & 26 & 60,5 & 17 & 39,5 & 43 & 100
\end{tabular}

Hasil uji statistik diperoleh nilai $p$-value $=0,000$. Oleh karena nilai $p<\alpha$ $(0,05)$, maka dapat disimpulkan bahwa ada perbedaan proporsi kejadian Kurang Energi Kronis (KEK) responden yang pemeriksaan kehamilan ANC baik dan responden yang pemeriksaan kehamilan ANC kurang (ada hubungan antara

\section{Pembahasan}

\section{1)Hubungan Pengetahuan Ibu Hamil} Tentang Gizi dengan Kejadian Kurang Energi Kronis (KEK)

Hasil penelitian menunjukkan ada hubungan yang bermakna antara pengetahuan dengan Kejadian Kurang Energi Kronis (KEK) dan ditemukan data bahwa responden yang berpengetahuan kurang 2,2 kali lebih beresiko menderita Kurang Energi Kronis (KEK) dibandingkan dengan responden yang berpengetahuan baik. Hasil ini sesuai dengan penelitian yang dilakukan oleh: (1)Ningrum (2010), peyakit infeksi dengan Kejadian Kurang Energi Kronis). Serta dari uji statistik juga di dapat nilai RR sebesar 2,700. Responden yang pemeriksaan kehamilan ANC kurang 2,7 kali lebih beresiko menderita Kurang Energi Kronis (KEK) dibandingkan dengan responden yang pemeriksaan kehamilan ANC baik.

mengenai Faktor - Faktor yang Berhubungan dengan Risiko Kurang Energi Kronis (KEK) pada Ibu Hamil di Kecamatan Pancoran Mas Kota Depok Jawa Barat Tahun 2010 ; (2) Palimbo (2014) yang berjudul Hubungan Pengetahuan dan Sikap Ibu Hamil Terhadap Kejadian Kurang Energi Kronis (KEK) di Wilayah Kerja Puskesmas Pulau Telo Banjarmasin Tahun 2014; (3) Lubis (2015) yang berjudul Faktor - Faktor yang Berhubungan dengan Kejadian Kekurangan Energi Kronis (KEK) pada 
Ibu Hamil di Puskesmas Langsa Lama Kota Langsa Tahun 2015.

Pengetahuan yang dimiliki oleh seorang ibu akan memengaruhi dalampengambilan keputusan dan juga akan berpengaruh pada perilakunya. Ibudengan pengetahuan gizi yang baik kemungkinan akan memberikan gizi yangcukup pada bayinya hal ini lebih penting lagi apabila ibu memasuki masa ngidam, yang biasanya perut enggan dimasuki makanan apapun yang bergizi, karenarasa mual yang dirasakan, justru akan memilih makanan dengan rasa segar danasam. Walaupun dalam kondisi yang demikian apabila seorang ibu memilikipengetahuan yang baik maka ibu tersebut akan berusaha untuk memenuhikebutuhan gizinya dan juga bayinya (Proverawati, 2009)

\section{2)Hubungan Penyakit Infeksi dengan Kejadian Kurang Energi Kronis (KEK)}

Hasil Penelitian menunjukkan adanya hubungan antara penyakit infeksi dengan Kejadian Kurang Energi Kronis (KEK).Hal ini sesuai dengan penelitian yang dilakukan Mulyaningrum (2009), yang berjudul "Faktor - Faktor yang Berhubungan dengan Risiko Kurang Energi Kronis (KEK) pada Ibu Hamil di Provinsi DKI Jakarta Tahun 2009" menunjukkan adanya hubungan yang bermakna antara penyakit infeksi dengan kejadian KEK.

Penyakit infeksi dapat bertindak sebagai pemula terjadinya kurang gizi sebagai akibat menurunya nafsu makan, adanya gangguan penyerapan dalam saluran pencernaan atau peningkatan kebutuhan zat gizi oleh adanya penyakit.Kaitan penyakit infeksi dengan keadaan gizi kurang merupakan hubungan timbalbalik, yaitu hubungan sebab akibat. Penyakit infeksi dapat memperburuk keadaangizi dan keadaan gizi yang jelek dapat mempermudah infeksi. Penyakit yangumumnya terkait dengan masalah gizi antara lain diare, tuberkulosis, campak danbatuk rejan (Supariasa, 2002).

Menurut Suhardjo (1996) dalam Ningrum (2010), status gizi merupakan bagian penting dari status kesehatan seseorang. Tidak hanya status gizi yang mempengaruhi kesehatan tetapi status kesehatan juga mempengaruhi status gizi. Infeksi dan demam dapat menyebabkan merosotnya nafsu makan atau menimbulkan kesulitan menelan dan mencerna makanan. Parasite dalam usus seperti cacing gelang dan cacing pita bersaing dengan tubuh dalam memperoleh makanan dan dengan demikian menghalangi zat gizi kedalam arus darah. Keadaan demikian membantu terjadinya kurang gizi. Supariasa (2001) dalam Ningrum (2010), menyatakan bahwa ada hubungan yang sangat erat antara interaksi (bakteri, virus dan parasite) dengan malnutrisi

\section{3)Hubungan Pemeriksaan Kehamilan ANC (Antenatal Care) dengan Kejadian Kurang Energi Kronis (KEK)}

Hasil penelitian menunjukkan ada hubungan yang bermakna antara pemeriksaan kehamilan ANC dengan Kejadian Kurang Energi Kronis (KEK). Responden yang pemeriksaan kehamilan ANC kurang 2,7 kali lebih beresiko menderita Kurang Energi Kronis (KEK) dibandingkan dengan responden yang pemeriksaan kehamilan ANC baik. Hal ini sejalan dengan dengan hasil 
penelitian yang dilakukan Lubis (2015), tentang Faktor-Faktor yang Berhubungan dengan Kejadian Kurang Energi Kronik (KEK) pada Ibu Hamil di Wilayah Kerja Puskesmas Langsa Lama Kota Langsa Tahun 2015 menunjukkan adanya hubungan yang bermakna antara pemeriksaan kehamilan ANC dengan kejadian Kurang Energi Kronis (KEK) pada ibu hamil dan didukung oleh hasil penelitian Mardatun (2015), tentang Hubungan Riwayat ANC (Antenatal Care) dan Tingkat Konsumsi Fe (Zat Besi) dengan Kejadian Kurang Energi Kronis (KEK) Ibu Hamil di Provinsi Nusa Tenggara Barat Tahun 2015 yang menemukan adanya hubungan yang bermakna antara riwayat ANC dengan kejadian KEK .

Menurut Saifudi (2005) dalam Mardiatu (2015), kunjungan ANC (Antenatal care) adalah kunjungan ibu hamil ke petugas kesehatan sedini mugkin semenjak ia merasa dirinya hamil untuk mendapatkan pelayanan/asuhan antenatal. Pada setiap kunjungan Antenatal Care (ANC) petugas mengumpulkan data dan menganalisis kondisi ibu melalui pemeriksaan fisik untuk mendapatkan diagnosis kehamilan serta ada tidaknyan masalah atau komplikasi kehamilan.

\section{Kesimpulan}

Berdasarkan hasil penelitian yang telah dilakukan di wilayah kerja Puskesmas Warung Jambu Kota Bogor tahun 2017 dapat disimpulkan bahwa; (1) terdapat hubungan yang bermakna antara pengetahuan dengan Kejadian Kurang Energi Kronis (KEK) pada ibu hamil di Puskesmas Warung Jambu Kota Bogor; (2) terdapat hubungan antara peyakit infeksi dengan Kejadian
Kurang Energi Kronis (KEK) pada ibu hamil di Puskesmas Warung Jambu Kota Bogor, dan; (3) terdapat hubungan yang bermakna antara pemeriksaan kehamilan ANC dengan Kejadian Kurang Energi Kronis (KEK).

Saran ditujukan kepada petugas Kesehatan diharapkan mampu meningkatkan upaya pendidikan kesehatan dalam bentuk peyuluhan mengenai bahaya KEK pada ibu hamil dan materi lain yang terkait dengan pentingnya pemenuhan gizi pada ibu hamil, serta meningkatkan pemberdayaan masyarakat untuk pencapaian cakupan pemeriksaan kehamilan pada tenaga kesehatan.

\section{Referensi}

[1] Arikunto, Suharsimi. (2013). Prosedur Penelitian Suatu Pendekatan Praktik. Jakarta : Rineka Cipta

[2] Arisman, (2008). Gizi dalam Daur Kehidupan. Jakarta : Penerbit Buku Kedokteran EGC.

[3] Arisman. (2010). Gizi dalam Daur Kehidupan. Edisi Ke 2. Jakarta: Penerbit BukuKedokteran. EGC.

[4] Badan Penelitian dan Pengembangan Kesehatan Kemeterian kesehatan RI. (2013). Riset Kesehatan dasar Tahun 2013. Jakarta : Kemenkes

[5] Dinas Kesehatan Kota Bogor. (2016). Profil Kesehatan Dinas Kesehatan Kota Bogor. Bogor : Dinkes.

[6] Hapni, Yenti. (2004). Faktor-Faktor ynag Berhubungan dengan Risiko Kurang Energi Kronis (KEK) pada Ibu Hamil di Pulau Kelapa Kepulauan Seribu DKI Jakarta Tahun 2004. Jakarta. Fakultas Kesehatan Masyarakat Universitas Indonesia.

[7] Hastono, Suntanto Priyo. (2014). Analisi Data. Depok. Fakultas Kesehatan Masyarakat Universitas Indonesia.

[8] Istiany, Ari \& Rusilanti. (2009). Gizi Terapan. Bandung: PT. Remaja Rosdakarya. 
[9] Kementerian Kesehatan RI. (1997). Buku Kesehatan Ibu dan Anak. Jakarta : Kemenkes dan JICA (Japan International Cooperation Agency).

[10] Kementerian Kesehatan RI. (2014). PERMENKES RI No 23 Tahun 2014 Tentang Upaya Perbaikan Gizi. Kemenkes RI.

[11] Kementerian Kesehatan RI. (2014). PERMENKES RI No 42 Tahun 2013 Tentang Gerakan Percepatan Perbaikan Gizi. Kemenkes RI.

[12] Kementerian Kesehatan RI. (2015). Rencana Strategi Kementerian Kesehatan Tahun 2015-2019. Jakarta : Kemenkes

[13] Kementerian Kesehatan RI. (2014). PERMENKES RI No 75 Tahun 2013 Tentang Angka Kecukupan Gizi yang Dianjurkan Bagi Bangsa Indonesia. Kemenkes RI.

[14] Lubis, Lili. (2015). Fakto-Faktor yang Berhubungan dengan Kejadian Kurang Energi Krinis (KEK) pada Ibu Hamil di Puskesmas Langsa Lama Kota Langsa Tahun 2015. Langsa: Fakultas Kesehatan Sumatera Utara.

[15] Mardatun. (2015). Hubungan Riwayat Antenatal Care (ANC) dan Tingkat Konsumsi $\mathrm{Fe}$ (Zat Besi) dengan Kejadian Kurang Energi Kronis (KEK) Ibu hamil di Provinsi Nusa Tengga Barat dan di Daerah Istimewa Jogjakarta. Penelitian Sisitem Kesehatan. Volume 18. Nomor 3. 221228.

[16] Mary E. Beck. (2011). Ilmu Gizi dan Diet. Yogyakarta: Penerbit Andi.

[17] Mulyaningrum, Sri. (2009). FaktorFaktor yang Berhubungan dengan Risiko Kurang Energi Kronis (KEK) pada Ibu Hamil di Provinsi DKI Jakarta Tahun 2009.Depok : Fakultas Kesehatan Masyarakat Universitas Indonesia.

[18] Nikmah, Umi Nahdrotun. (2015). Hubungan Pengetahuan tentang Gizi dengan Kejadian Kurang Energi Kronis (KEK) Pada Ibu Hamil Di Wilayah Puskesmas Bringin Kabupaten Semarang. Semarang. Sekolah Tinggi Ilmu Kesehatan Ngudi Waluyo Ungaran

[19] Ningrum, Riska Ayu. (2010). FaktorFaktor yang Berhubungan dengan
Risiko Kurang Energi Kronis (KEK) pada Ibu Hamil di Kecamatan pncoran Mas Kota Depok Jawa Barat tahun 2010. Depok :fakultas Kesehatan Masyarakat Universitas Indonesia

[20] Notoatmodjo, Soekidjo. (2011).Metodologi Penelitian Kesehatan, edisi revisi. Jakarta : PT. Rineka Cipta.

[21] Notoatmodjo, Soekidjo. (2011). Kesehatan Masyarakat Ilmu dan Seni. Jakarta : PT. Rineka Cipta

[22] Notoatmodjo, Soekidjo. (2012). Kesehatan Masyarakat Ilmu dan Seni. Jakarta : PT. Rineka Cipta

[23] Palimbo, Adriana. (2014). Hubungan Pengetahuan dan Sikap Ibu Hamil terhadap Kejadian Kurang Energi Kronis (KEK) di Wilayah Puskesmas Pulau Telo Kuala Kapuas Banjarmasin Tahun 2014. Jurnal Dinamika Kesehatan. Volume 14.

[24] Peraturan Meteri Kesehatan RI. (2016). Standar Produk Suplementasi Gizi Jakarta : Kemenkes RI.

[25]--- (2015). Pedoman Penyusunan Skripsi. Bogor : Fakultas Kesehatan Masyarakat Universitas Ibn Khaldun

[26] Proverawati, Atikah \& Siti Asfuah. (2009). Buku Ajar Gizi Untuk Kebidanan.Yogyakarta: Nuha Medika.

[27] Purwitasari, Desi dan Dwi Maryanti (2009). Gizi dalam Kesehatan Reproduksi. Yogyakarta: Nuha Medika.

[28] Puskesmas Warung Jambu. (2016). Profil Kesehatan Puskesmas Warung Jambu Tahun 2016. Puskesmas Warung Jambu Kota Bogor.

[29] Puskesmas Warung Jambu. (2016). LB3 Puskesmas Warung Jambu Tahun 2016. Puskesmas Warung Jambu Kota Bogor.

[30] Puskesmas Warung Jambu. (2016). Laporan Gizi Puskesmas Warung Jambu Tahun 2016. Puskesmas Warung Jambu Kota Bogor.

[31]Riset Kesehatan Dasar. (20130. Prevalensi Risiko KEK Wanita hamil Umur 15-45 Tahun Provinsi, Indonesia Tahun 2013. Riskesdas.

[32]Riset Kesehatan Dasar. (2013). Prevalensi Risiko KEK Wanita Usia Subur Menurut Umur, Indonesia Tahun 2007-2013. Riskesdas. 
[33] Rukiah, Ai yeyeh. (2010). Asuhan Kebidanan. Jakarta : TIM

[34] Siti Misaroh Ibrahim. M, \& Atikah Proverawati. (2010). Nutrisi Janin \& Ibu Hamil Cara Membuat Otak Janin Cerdas. Yogyakarta: Nuha Medika

[35] Soetjiningsih, IGN Ranuh. (1995). Tumbuh Kembang Anak. Jakarta : EGC

[36] Sugiyono, et.al. (2014). Metodologi Penelitian Kuantitatif dan $R \& D$. Bandung : Alfabeta.

[37] Sunita, Almatsier. (2007). Penuntun Diet. Cetakan Keduapuluh Tiga. Jakarta: PT. Gramedia Pustaka Utama.

[38] Supariasa, I Dewa Nyoman. (2002). Penilaian Status Gizi. Jakarta : EGC
[39] Surasih, Halym. (2005). Faktor-Faktor Yang Berhubungan Dengan Keadaan Kurang Energi Kronis (KEK) Pada Ibu Hamil Di Kabupaten Banjarnegara Tahun 2005.Semarang : Fakultas Ilmu Keolahragaan Universitas Negeri Semarang.

[40] Yulisastuti, Erni. (2014). Faktor-Faktor yang Berhubungan dengan kurang Energi Kronis (KEK) pada Ibu Hamil di Wilayah Kerja Puskesmas Sungai Bilu Banjarmasin Tahun 2014. Jurnal An, Nada. Volume 1, Nomor 2, 72-76 